\title{
Appraisal of Rainwater Harvesting in ASCOT Engineering Zabali Campus Baler Aurora
}

\author{
Nelson L. Sibayan ${ }^{1}$, Christopher S. Paladio ${ }^{2}$, Jeremi S. Lopez ${ }^{3}$, Lorinda E. Pascual ${ }^{4}$
}

\begin{abstract}
One of the problems encountered by the engineering students and faculty and staff members of Aurora State College of Technology (ASCOT) is the water supply for toilet and urinal flushing. This problem is attributed to the location of the area which is $50 \mathrm{~m}$ above sea level. The main water source of the campus is the water coming from water falls which requires pipelines that are vulnerable from heavy damage during natural disasters and illegal intrusion. To address the scarcity, rainwater harvesting is considered by the researchers and in this research, the researchers assessed the potential of rainwater harvesting using the roof of an existing building in the area. The result shows that harvesting water from rainfall can become a solution in the scarcity of water in the area. Based on 10-year rainfall data from PAGASA Baler Station Complex which is Located approximately $4.3 \mathrm{~km}$ from the location of the study that on average, during December, November and October the amount of rainfall can fulfill the demand of water for toilet and urinal flushing up to $102.54 \%, 76.98 \%$ and $75.40 \%$ respectively. The total area of rainwater collector in this study is about 186.87 square meter. Data also shows that on average, the month of August has the minimum potential of fulfilling the demand water for the area but by increasing the area of collector by $68 \%, 100 \%$ of the demand for this specific purpose maybe met during the driest month of the year.
\end{abstract}

KEYWORD: Rainwater Harvesting, Water, Rainfall, Baler Aurora

\section{INTRODUCTION}

The application of this research is only limited to ASCOT, specifically, the Department of Engineering. ASCOT was founded on December 30, 1993 by the virtue of R.A No. 7664. It was formulated by then Senate President Edgardo J. Angara and the late Congressman Benedicto G. Miran. Right away, a pre-arranged task force was formed to facilitate the operation and management of ASCOT headed by Senator Angara. Negotiations and arrangement were organized with then Department of Education, Culture and Sports (DECS), Division of Aurora, represented by Superintendent, Mr. Domingo F. Hulipas. Temporary classrooms were assigned to be used for the following school year and managed the admission of students.

ASCOT's operation started year 1993, headed by the acting President, Dr. Benny A. Palma. . ASCOT started with 301 freshmen, whose classes were conducted at Baler Central School (BCS) buildings. 10 classrooms were prepared for the students and another room that served as administration office. 22 personnel, including 13 faculty members and 9 administrative personnel were tasked to serve the student.

A campus site was given to ASCOT containing 196.06 hectares of land located at Dibudulan Mountain, Sitio Dicaloyungan, Brgy. Zabali, Baler, Aurora through RA 7664. Thru the P.P. No. 559 on April 7, 1996, the area was proclaimed as a school site for ASCOT. The Proclamation also required ASCOT to integrate the Aurora National Fishery (ANFish) School in Casiguran, Aurora and the Aurora National Agricultural School (ANAS) in the town of Maria Aurora, Aurora. With this, two campuses with 110.8 hectares of land in Barangay Bazal, Maria Aurora and 105 hectares in Barangay Bianoan, Casiguran, Aurora were also obtained by ASCOT through a Memorandum of Agreement with the Department of Education, Culture and Sports represented by Regional Director Pedro V. Trinidad of Region IV. The Diploma in Agricultural TechnologyBachelor of Agricultural Technology (DAT-BAT) program including 10 faculty members, 2 staff, 259 students, books, vehicles, equipment and building were also turned over to ASCOT (ASCOT Administration Manual).

In order to give quality education and conducive environment for the students, facilities of the College should be improved like classrooms, electricity, enough water supply, comfort rooms, etc. Also, the College should address problems that are long overdue and needs immediate solutions. One of the major problems currently encountered by faculty members, students, and even the stakeholders in ASCOT is the shortage of water supply for the maintenance of cleanliness in the comfort room of the facility, particularly at the Engineering Building. The Engineering Building is located on top of the Dibudulan Mountain in Zabali Baler Aurora with an elevation fifty (50) meters above sea level. Due to its elevation, it is very difficult to pump the water going to the building and the

Nelson L. Sibayan ${ }^{1}$, ETJ Volume 6 Issue 06 June 2021 
cost to design a water system with this situation is quite expensive. Most of the water supply of the building comes from the free flowing coming from waterfalls but it is not reliable because of illegal intrusion which leads to disruption of water. To address the water problem at the Engineering Building, the researchers want to increase the source of water thought utilization of rainwater. The rainwater will be collected from the roof of an existing Engineering Building that is to be used as the water source needed for toilet and urinal flushing.

This study aims to:

1. Assess the possibility of rain water harvesting in ASCOT Engineering Building.

2. Calculate the demand of water for toilet and urinal flushing of ASCOT Engineering Building specifically for urinal and toilet flushing.

3. Determine the capacity of the proposed rainwater collector to fulfill the demand of water for toilet and urinal flushing of ASCOT Engineering Building.

The importance of this study is:

1. The proponent will be able calculate the potential of the rainwater collector in ASCOT Engineering.

2. The proponent will have a basis in developing a design of a rainwater harvester for ASCOT Engineering

The water demand is increasing leading to scarcity, in order to provide solutions to the water demand problems, different countries are building large-scale projects like dams, pipelines, pumping station, etc. but in spite of these projects, problems still persist. In addition to this, some of those largescale projects have impacts to the environment. Before the development of these large-scale projects, rainwater harvesting has been adopted. Nowadays, some studies revealed that interest in rain water harvesting has been continually increasing. Stavros, Y. et al (2019).

Although rainwater harvesting is on its trend, experts found out that the lack of specialized rain water harvesting organization and absence of technical information are main barriers why citizens of Iran are hesitant to adopt rain water harvesting. With a suitable policy making and strategic planning, rain water harvesting can be considered as sustainable development technology which can serve community well. Vahedberdi Sheikh (2020). There are also researches being conducted regarding the utilization of rain water all over the globe. According to Notaro et al. (2016), due to an increase in water demand resulting from rapid growth of population and the enlargement of urban and industrialized areas, water scarcity became a serious problem. Climate change will continue to have a negative effect on water resources and one of the arising solutions to face water scarcity is Rainwater Harvesting (RWH). A study of Rainwater Harvesting System reliability analysis was used to analyze the effectiveness of an RWH system installed to supply water for toilet to a residential area of Sicily (Southern Italy). Benefits and opportunities from rainwater harvesting is imminent particularly in tropical countries like in developing countries. A related research was conducted by Helmreich \& Horn (2009) regarding the opportunities in rainwater harvesting. According to their research, lack of water supply is becoming a problem in most countries. The amount of rainfall adds up to a possible water supply. In addition, a correct and systematic use could lessen food and water crisis in some of these regions.

Rainwater harvesting (RWH) is a technology where rain is collected and stored instead of allowing it to run off. For easier access, RWH systems should be based on local skills, materials and equipment. ASCOT Engineering Building which will serve as rainwater collector is located in Sitio Dicaloyungan, Brgy. Zabali, Baler, Aurora, Philippines. In this paper, the harvesting potential of the roof of Engineering building will be estimated using the rainfall data from PAGASA Baler Station Complex (Philippine Atmospheric, Geophysical and Astronomical Services Administration) located on the same mountain with an approximate distance of $4.3 \mathrm{~km}$ from the locale of the study. This will provide a quantifiable analysis on the potential of RWH which may be possibly utilized as a source of water for the toilet and urinal flushing of Engineering Area of ASCOT Zabali Campus Baler Aurora.

\section{MATERIALS AND METHODS}

Engineering Building of ASCOT is Located at Sitio Dicaloyungan Brgy. Zabali Baler Aurora, Philippines $\left(15^{\circ} 44^{\prime} 31.03 " \mathrm{~N}, 121^{\circ} 31^{\prime} 43^{\prime \prime} \mathrm{E}\right)$ with an average Annual Temperature is $24^{\circ} \mathrm{C}$. The roof of Engineering Building is the proposed rainwater collector. It has an effective roof area of 186.87 square meter. 
"Appraisal of Rainwater Harvesting in ASCOT Engineering Zabali Campus Baler Aurora"

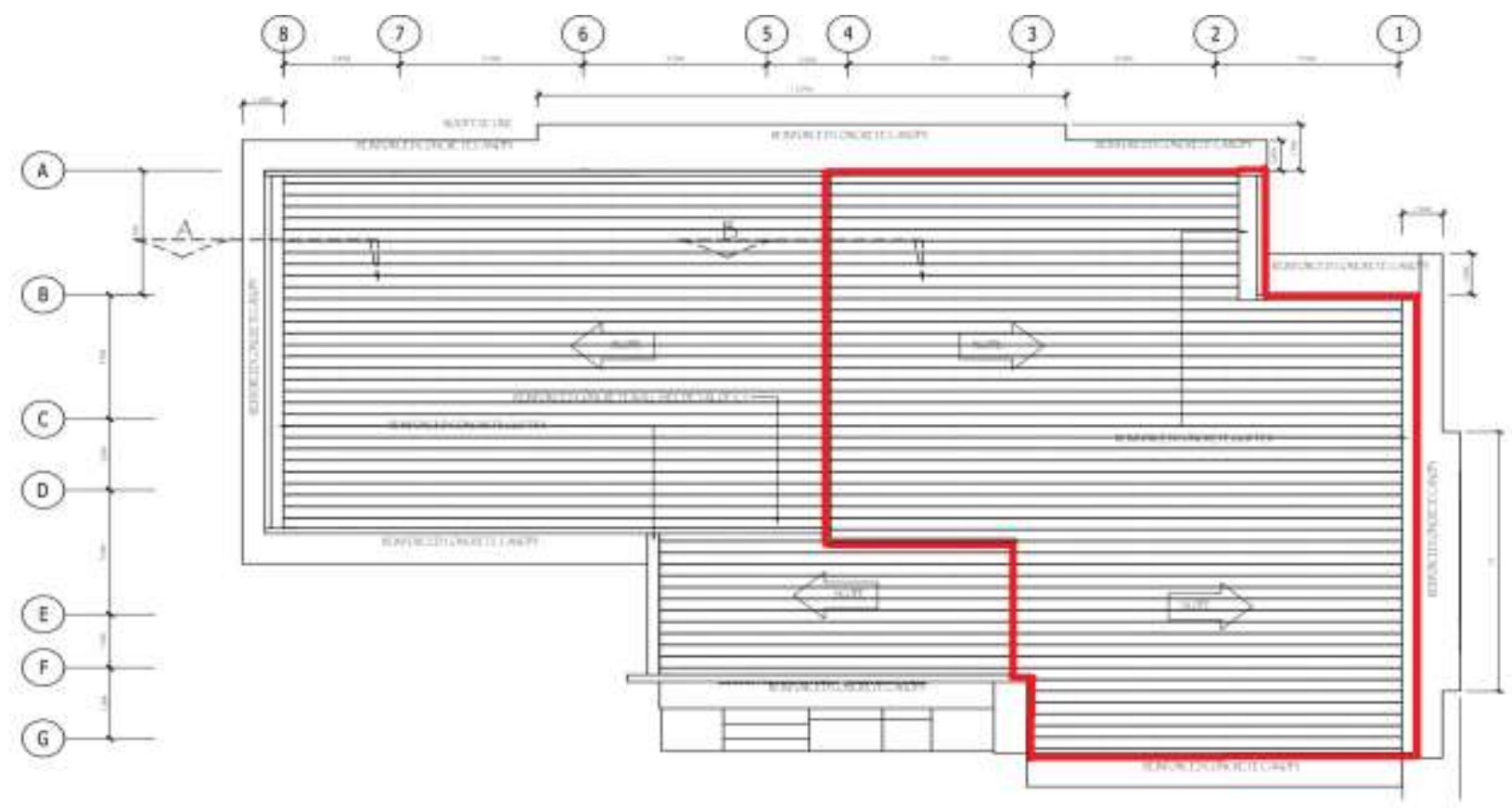

Figure 1. Roof Plan of Engineering Building Showing the Effective Roof Area to be used as Rainwater Collector

\section{METHODS}

Material used in this roof is smooth surface painted metal roofing. The amount of rainwater to be collected is based on the area of the collector, rainfall depth and surface runoff which is dependent on the materials and design of roof. The estimated runoff coefficient for sloping smooth roof is about 0.90 (Ramon Farreny Et. Al 2011). To estimate the potential of the proposed rainwater collector, ten years rainfall data was gathered thru the help of Baler PAGASA Station Complex and then analyzed to ascertain the rainfall pattern and monthly average rainfall considering the wet and dry season occurring in this locale. The possible amount of water to be collected from the proposed rainwater collector was determined using the following equation:

$$
V R=\frac{R \times H_{R A} x R_{C}}{1000}
$$

VR - Volume of water collected from rainwater collector per month
$\mathrm{R}$ - Monthly rainfall in millimeter

$\mathrm{H}_{\mathrm{RA}}-$ area of roof in square meter

$\mathrm{R}_{\mathrm{C}}-$ Runoff coefficient

This equation was adopted from Ghisi et. al (2006).

The total population who are potentially occupying the building was also gathered from the office of the registrar of ASCOT Zabali Campus. This data was used as basis in the computation of water requirements for urinal and toilet flushing. The estimated requirements of water for urinal and toilet flushing in the Philippines is 7.63 liters per capita per day (Inocencio 1999).

Coefficient of variation was also determined using the following formula:

$$
C V=\frac{S D}{A V E R A G E}
$$

Wherein $\mathrm{CV}$ is the Coefficient of variation and $\mathrm{SD}$ is the standard deviation.

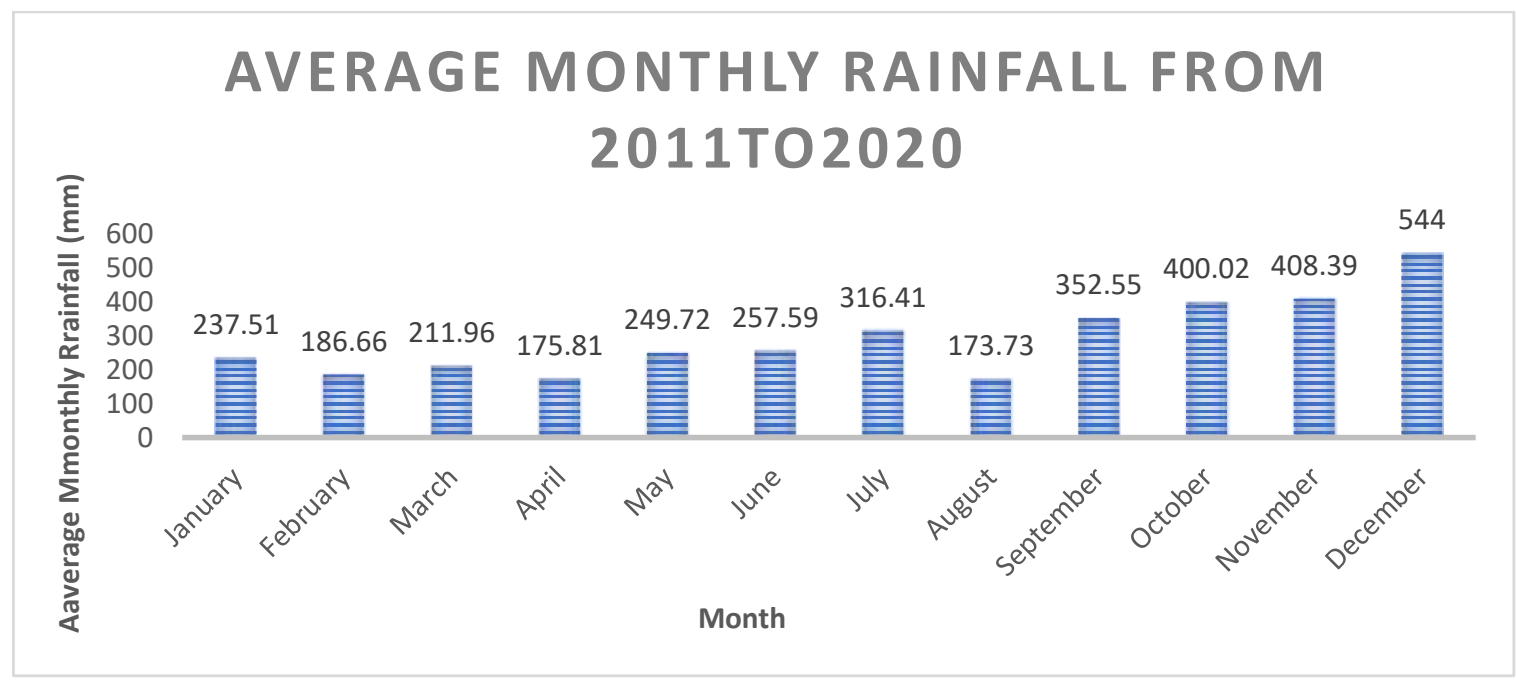

Figure 2 
"Appraisal of Rainwater Harvesting in ASCOT Engineering Zabali Campus Baler Aurora"

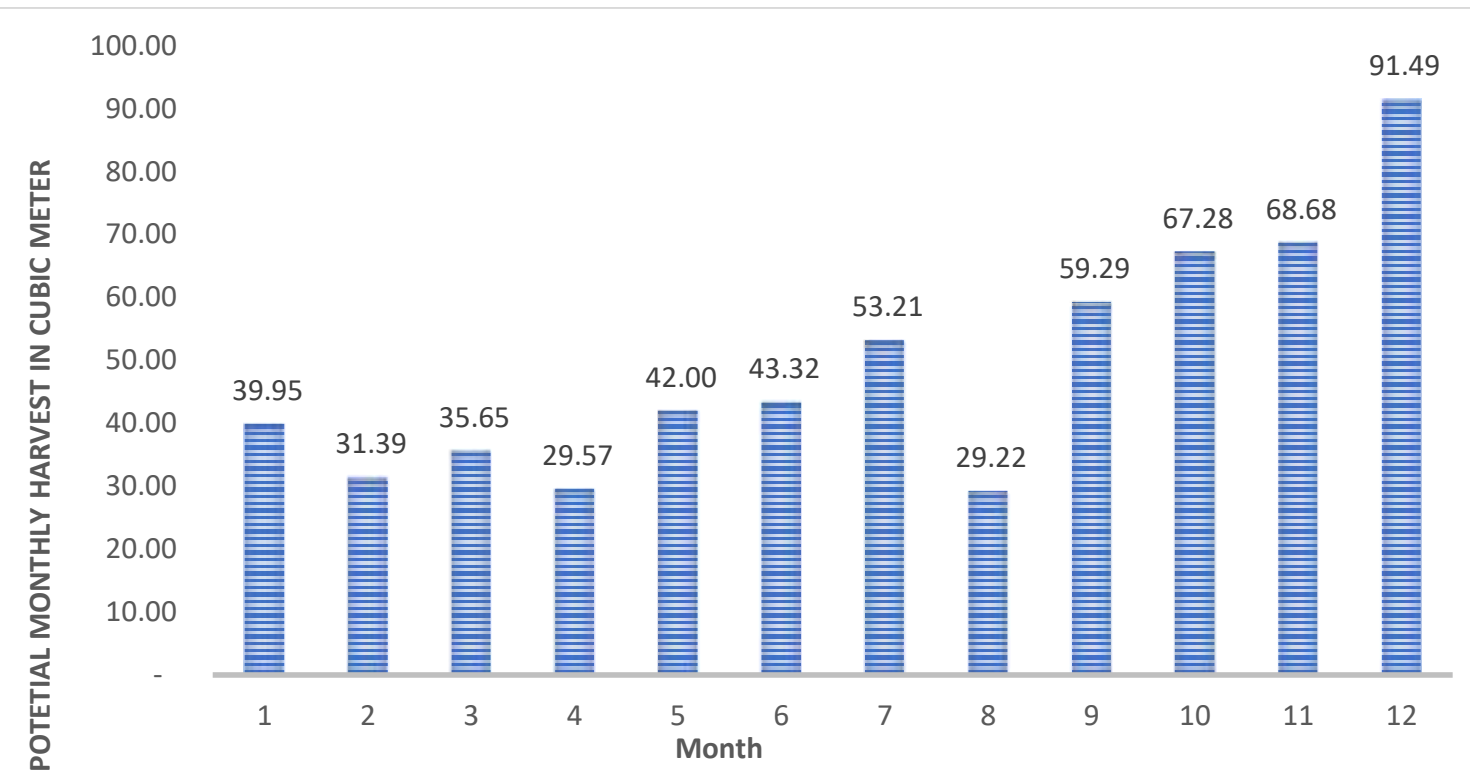

Figure 3

\section{RESULT AND DISCUSSION}

MONTHLY RAINFALL DEPTH FROM 2011-2015 (mm)

Table 1

\begin{tabular}{|l|l|l|l|l|l|}
\hline & 2011 & 2012 & 2013 & 2014 & 2015 \\
\hline January & 238.5 & 163.6 & 204.7 & 33.4 & 96.5 \\
\hline February & 17 & 290.9 & 438.4 & 132.2 & 120.8 \\
\hline March & 169.7 & 464.3 & 325.6 & 339.6 & 154.1 \\
\hline April & 217 & 139.8 & 204 & 107.6 & 159.6 \\
\hline May & 212.8 & 151.4 & 195.9 & 103.3 & 56.6 \\
\hline June & 593.6 & 39.6 & 288.6 & 42.4 & 140 \\
\hline July & 317.3 & 315.6 & 611.6 & 140.7 & 115.6 \\
\hline August & 200.2 & 181.3 & 248.9 & 248.9 & 51.8 \\
\hline September & 344.1 & 648.4 & 358.5 & 294.1 & 319.8 \\
\hline October & 365.5 & 682 & 232.7 & 365.3 & 285.1 \\
\hline November & 855.5 & 244 & 439.7 & 167.6 & 132.7 \\
\hline December & 772 & 287.8 & 860.5 & 204.7 & 1026.8 \\
\hline
\end{tabular}

MONTHLY RAINFALL DEPTH FROM 2016-2020 (mm)

\begin{tabular}{|l|l|l|l|l|l|l|}
\hline & 2016 & 2017 & 2018 & 2019 & 2020 & $\begin{array}{l}\text { MONTHLY AVERAGE } \\
\text { RAINFALL (mm) }\end{array}$ \\
\hline January & 144.4 & 622 & 303 & 281.7 & 287.3 & 237.51 \\
\hline February & 155.4 & 429.6 & 127.5 & 69 & 85.8 & 186.66 \\
\hline March & 183.4 & 237.4 & 152.4 & 48.9 & 44.2 & 211.96 \\
\hline April & 171.6 & 151.2 & 192.7 & 226.7 & 187.9 & 175.81 \\
\hline May & 293.7 & 411.2 & 287.7 & 404.7 & 379.9 & 249.72 \\
\hline June & 324.9 & 382.2 & 185.8 & 201.3 & 377.5 & 257.59 \\
\hline July & 140.4 & 624.4 & 316.2 & 217.8 & 364.5 & 316.41 \\
\hline August & 133.6 & 244.6 & 95.8 & 54.1 & 278.1 & 173.73 \\
\hline
\end{tabular}


"Appraisal of Rainwater Harvesting in ASCOT Engineering Zabali Campus Baler Aurora"

Table 2

\begin{tabular}{|l|l|l|l|l|l|l|} 
September & 188.4 & 337.6 & 387.6 & 247.3 & 399.7 & 352.55 \\
\hline October & 470.6 & 283 & 317.9 & 202.4 & 795.7 & 400.02 \\
\hline November & 619.1 & 885.9 & 102.7 & 148.2 & 488.5 & 408.39 \\
\hline December & 452.4 & 179 & 422.8 & 445.9 & 788.1 & 544 \\
\hline
\end{tabular}

Data shows that there is an occurrence of rain even during the dry season from 2011 to 2020. The greatest amount of rain occurs during the month of September, October, November and December with an average monthly rainfall of $352.55 \mathrm{~mm}, 400.02 \mathrm{~mm}, 408.39 \mathrm{~mm}$ and $544 \mathrm{~mm}$ respectively. The minimum amount of rainfall on average during the period of ten years occurs during the month of August and April with an average amount of rainfall of $173.73 \mathrm{~mm}$ and $175.81 \mathrm{~mm}$ respectively. The total number of persons which are considered as potential occupants of ASCOT Engineering as of 2021 is 587 person and the daily amount of water needed for the toilet and urinal flushing is 7.63liters per capita per day (Inocencio 1999) which gives the total demand per month of 89.22 cubic meter (excluding Saturdays and Sundays with no schedule of classes).

\begin{tabular}{|l|l|l|l|l|}
\hline MONTH & $\begin{array}{l}\text { MONTHLY } \\
\text { AVERAGE }\end{array}$ & $\begin{array}{l}\text { MONTHLY } \\
\text { HARVEST } \\
\text { (cu.m) }\end{array}$ & $\begin{array}{l}\text { MONTHLY } \\
\text { DEMAND } \\
\text { (cu.m) }\end{array}$ & $\begin{array}{l}\text { PERCENT OF } \\
\text { FULFILLED } \\
\text { DEMAND }\end{array}$ \\
\hline JANUARY & 237.51 & 39.95 & 89.22 & $44.77 \%$ \\
\hline FEBRUARY & 186.66 & 31.39 & 89.22 & $35.18 \%$ \\
\hline MARCH & 211.96 & 35.65 & 89.22 & $39.95 \%$ \\
\hline APRIL & 175.81 & 29.57 & 89.22 & $33.14 \%$ \\
\hline MAY & 249.72 & 42.00 & 89.22 & $47.07 \%$ \\
\hline JUNE & 257.59 & 43.32 & 89.22 & $48.55 \%$ \\
\hline JULY & 316.41 & 53.21 & 89.22 & $59.64 \%$ \\
\hline AUGUST & 173.73 & 29.22 & 89.22 & $32.75 \%$ \\
\hline SEPTEMBER & 352.55 & 59.29 & 89.22 & $66.45 \%$ \\
\hline OCTOBER & 400.02 & 67.28 & 89.22 & $75.40 \%$ \\
\hline NOVEMBER & 408.39 & 68.68 & 89.22 & $76.98 \%$ \\
\hline DECEMBER & 544 & 91.49 & 89.22 & $102.54 \%$ \\
\hline
\end{tabular}

Table 3. Potential Harvest Based on Monthly Average Rainfall and Percentage of Fulfilled Demand

\begin{tabular}{|l|l|l|l|l|}
\hline MONTH & $\begin{array}{l}\text { MINIMUM } \\
\text { RAINFALL (mm) }\end{array}$ & $\begin{array}{l}\text { MONTHLY } \\
\text { HARVEST (cu.m) }\end{array}$ & $\begin{array}{l}\text { MONTHLY } \\
\text { DEMAND } \\
\text { (cu.m) }\end{array}$ & $\begin{array}{l}\text { PERCENT OF } \\
\text { FULLFILED } \\
\text { DEMAND }\end{array}$ \\
\hline JANUARY & 33.4 & 5.62 & 89.22 & $6.30 \%$ \\
\hline FEBRUARY & 17 & 2.86 & 89.22 & $3.20 \%$ \\
\hline MARCH & 48.9 & 8.22 & 89.22 & $9.22 \%$ \\
\hline APRIL & 151.2 & 25.43 & 89.22 & $28.50 \%$ \\
\hline MAY & 56.6 & 9.52 & 89.22 & $10.67 \%$ \\
\hline JUNE & 39.6 & 6.66 & 89.22 & $7.46 \%$ \\
\hline JULY & 140.4 & 23.61 & 89.22 & $26.46 \%$ \\
\hline AUGUST & 51.8 & 8.71 & 89.22 & $9.76 \%$ \\
\hline SEPTEMBER & 188.4 & 31.69 & 89.22 & $35.51 \%$ \\
\hline OCTOBER & 202.4 & 34.04 & 89.22 & $38.15 \%$ \\
\hline NOVEMBER & 102.7 & 17.27 & 89.22 & $19.36 \%$ \\
\hline DECEMBER & 179 & 30.10 & 89.22 & $33.74 \%$ \\
\hline
\end{tabular}

Table 4. Potential Harvest Based on Minimum Monthly Rainfall and Percentage of Fulfilled Demand 


\begin{tabular}{|l|l|l|l|l|}
\hline MONTH & $\begin{array}{l}\text { MAXIMUM } \\
\text { RAINFALL } \\
(\mathrm{mm})\end{array}$ & $\begin{array}{l}\text { MONTHLY } \\
\text { HARVEST } \\
(\mathrm{cu} . \mathrm{m})\end{array}$ & $\begin{array}{l}\text { MONTHLY } \\
\text { DEMAND (cu.m) }\end{array}$ & $\begin{array}{l}\text { PERCENT OF } \\
\text { FULLFILED } \\
\text { DEMAND }\end{array}$ \\
\hline JANUARY & 622 & 104.61 & 89.22 & $117.24 \%$ \\
\hline FEBRUARY & 438.4 & 73.73 & 89.22 & $82.64 \%$ \\
\hline MARCH & 464.3 & 78.09 & 89.22 & $87.52 \%$ \\
\hline APRIL & 226.7 & 38.13 & 89.22 & $42.73 \%$ \\
\hline MAY & 411.2 & 69.16 & 89.22 & $77.51 \%$ \\
\hline JUNE & 593.6 & 99.83 & 89.22 & $111.89 \%$ \\
\hline JULY & 624.4 & 105.01 & 89.22 & $117.70 \%$ \\
\hline AUGUST & 278.1 & 46.77 & 89.22 & $52.42 \%$ \\
\hline SEPTEMBER & 399.7 & 67.22 & 89.22 & $75.34 \%$ \\
\hline OCTOBER & 795.7 & 133.82 & 89.22 & $149.99 \%$ \\
\hline NOVEMBER & 885.9 & 148.99 & 89.22 & $166.99 \%$ \\
\hline DECEMBER & 1026.8 & 172.69 & 89.22 & $193.55 \%$ \\
\hline
\end{tabular}

Table 5

Potential Harvest Based on Maximum Monthly Rainfall and Percentage of Fulfilled Demand

On average, the demand for the toilet and urinal flushing were met during the month of December while $75 \%$ and $77 \%$ of demand were met during the month of October and November.

The intra annual variability of rainfall varies from 0.21 up to 0.79 while the inter annual variability is 0.27 which shows the high variability of rainfall in Baler Aurora. As a result, it makes the forecasting of rainfall difficult.

\section{CONCLUSION}

Based on the average monthly rainfall, $102 \%$ of the demand of water for urinal and toilet flushing were met during the month of December and the least potential amount of water which can be collected was during the month of August which fulfills only about $32 \%$ of the demand. This clearly shows that the area of existing collector must be increased by $68 \%$ to increase the capacity of collecting rainwater in fulfilling the demand of water for urinal and toilet flushing. It also shows that collecting rainwater has the possibility of fulfilling the demand of ASCOT Engineering Area because data shows that there is an occurrence of rainfall in this locale even during summer. Data also shows that in ten years, the frequency of 7 consecutive days with no rain is only 9 and 15 consecutive days with no rain occurs only once. It clearly shows that this area has a very low chance of having more than 15 consecutive days without rain in any season. By designing the proper and adequate storage and collector, rainwater harvesting may satisfy the demand of water for urinal and toilet flushing of Engineering Area of ASCOT Baler Aurora Philippines.

\begin{tabular}{|l|l|l|}
\hline 7 Days or More Without Rain & & Remark \\
\hline No. of days & frequency & \\
\hline 7 & 9 & \\
\hline 8 & 2 & \\
\hline 9 & 7 & \\
\hline 10 & 7 & \\
\hline 11 & 2 & \\
\hline 12 & 1 & \\
\hline 13 & 0 & \\
\hline 14 & 1 & \\
\hline 15 & 1 & June 21,2012 \\
\hline
\end{tabular}

Table 6

\section{REFERENCE}

1. Ghisi, E. et al (2006) Potential for potable water savings by using rainwater: An analysis over 62 cities in southern Brazil. Building and Environment 41 (2006) 204-21
2. Aladenola, O., Adeboye, O. (2009) Assessing the Potential for Rainwater Harvesting. Water Resource Manage (2010) 24:2129-213

3. Inocencio, A., Padilla, J., Javier E. (1999) Determination of Basic Household Water 
"Appraisal of Rainwater Harvesting in ASCOT Engineering Zabali Campus Baler Aurora"

Requirements. Philippine Institute for Development Studies.

4. Farreny, R. et al (2011) Roof selection for rainwater harvesting: Quantity and quality assessments in Spain. Water Research 45 (2011) 3245-3254

5. Stavros, Y. et al (2019) Investigation of the Current Situation and Prospects for the Development of Rainwater Harvesting as Tool to Confront Water Scarcity Worldwide, Water 2019, 11(10), 2168

6. Notaro V., Liuzzo L., Freni G. (2016). Reliability Analysis of Rainwater Harvesting Systems in Southern Italy. Proceedings: International Conference on Efficient \& Sustainable Water Systems Management toward Worth Living Development, 2nd EWaS 2016, Procedia Engineering 162 (2016) $373-380$.

7. MW Wardiha et. Al (2012) Compatibility of characteristic of Hydraulic Ram Pump and rain Harvest Technology with local characteristic in Ende. Widyariset, Vol. 15 No. 3, Desember 2012: $565-576$

8. Vahedberdi Sheikh (2020) Perception of Domestic rainwater Harvesting by Iranian Citizens, Sustainable Cities and Society 60 (2020) 102278

9. Helmreich B. \& Horn H. (2009). Opportunities in rainwater harvesting. Desalination 248 (2009) 118124. https://www.ascot.edu.ph/about/history/ 